University of Nebraska - Lincoln

DigitalCommons@University of Nebraska - Lincoln

Faculty Publications from the Harold W. Manter Laboratory of Parasitology

8-1959

\title{
Studies on the Helminth Fauna of Alaska. XXXIV. The Parasites of Wolves, Canis lupus L.
}

Robert L. Rausch

Arctic Health Research Center, rausch@u.washington.edu

Francis Williamson

Arctic Health Research Center

Follow this and additional works at: https://digitalcommons.unl.edu/parasitologyfacpubs

Part of the Parasitology Commons

Rausch, Robert L. and Williamson, Francis, "Studies on the Helminth Fauna of Alaska. XXXIV. The Parasites of Wolves, Canis lupus L." (1959). Faculty Publications from the Harold W. Manter Laboratory of Parasitology. 584.

https://digitalcommons.unl.edu/parasitologyfacpubs/584

This Article is brought to you for free and open access by the Parasitology, Harold W. Manter Laboratory of at DigitalCommons@University of Nebraska - Lincoln. It has been accepted for inclusion in Faculty Publications from the Harold W. Manter Laboratory of Parasitology by an authorized administrator of DigitalCommons@University of Nebraska - Lincoln. 
Rausch \& Williamson in Journal of Parasitology (August 1959) v. 45, no. 4, section 1.

Copyright 1959, American Society of Parasitologists. Used by permission.

\section{STUDIES ON THE HELMINTH FAUNA OF ALASKA. XXXIV. THE PARASITES OF WOLVES, CANIS LUPUS L. \\ Robert Rausch and Francis S. L. Williamson \\ Zoonotic Disease Section, Arctic Health Research Center, Public Health Service, U. S. Department of Health, Education, and Welfare, Anchorage, Alaska}

It is generally recognized that canine animals comprise an important reservoir of parasites and diseases transmissible to man. These animals, including the domestic dog, have unusual economic importance in arctic and subarctic North America, particularly for the Eskimos and Indians living in more remote regions. These aboriginal peoples continually have close association with canine animals and would appear to be quite vulnerable to infection from this source. That this is true is already evident, although data on morbidity from animal-borne diseases are far from complete. At the present time, at least in Alaska, these people have little ability to lessen the degree of exposure to zoonotic diseases, for poverty, ignorance of the problems, and adverse climatic conditions combine in making it difficult to effect sanitary practices necessary to prevent such exposures.

The investigation of parasites and diseases of canine animals in Alaska was initiated by Rausch in January, 1949. Many canids, representing 5 species, have been autopsied over the 10-year period, and it is believed that these surveys are now sufficiently complete to permit an evaluation of the potential importance of the helminths to human health. The findings for each canine species will be reported separately. It is the purpose of this paper to present observations on the helminths of wolves, Canis lupus L., with a review of pertinent literature.

\section{MATERIALS AND METHODS}

Most of the wolves available for this work were obtained as skinned carcasses of animals shot or trapped by Eskimos and Indians in interior Alaska. These were labelled by the hunters, as required, and stored frozen until they could be transported to the laboratory. By this means, we benefited from the efforts of many hunters and secured more wolves than would have been possible in any other way. Also, because wolves in Alaska are decreasing in numbers as a result of general persecution, we desired to avoid killing any for our purposes since material was otherwise available.

A few animals were autopsied in the field during the warmer months, but the majority was examined in the laboratory. The organs were opened separately and the helminths were isolated in water. Since the wolves could not be examined immediately after death, many of the cestodes collected were in poor condition and not satisfactory for detailed study. Cestodes and trematodes were stained in Semichon's acetic carmine, and permanent mounts were prepared. The rostellar hooks of the Taenia spp. were removed and mounted separately, making possible more detailed study. The species of Taenia were tentatively separated after making enlarged projections of the hooks by means of a prism attached to a microscope, and comparing them directly with the outlines of the hooks of known species. This method permitted a rapid preliminary sorting of the large number of cestodes collected. Final determinations were based upon all characters of diagnostic value. The nematodes were cleared in lactophenol and studied unmounted.

The helminths considered herein were obtained from 200 wolves, the majority of which had been killed during the period November 1 through April 15. No animals younger than 6-7 months were examined. The localities from which these wolves were taken are shown in Figure 1.

Received for publication January 7, 1959. 
Rausch \& Williamson in Journal of Parasitology (August 1959) v. 45, no. 4, section 1.

Copyright 1959, American Society of Parasitologists. Used by permission.

\section{RESULTS}

1. CESTODA

Genus Taenia Linnaeus, 1758

Species of Taenia were recorded from 182 wolves (91\% of the total). However, in view of the poor state of preservation of much of the material, the cestodes from only 78 animals were identified to species. Among the latter, 2 species occurred in 26 wolves, and 3 species were found in 13 . The maximum number of strobilae recorded from a single animal was 66.

\section{Taenia hydatigena Pallas, 1776}

T. hydatigena was identified in $56(72 \%)$ of 78 wolves. It has been recorded from this host in other North American localities by Erickson (1944) (Minnesota), and by Cowan $(1946 ; 1947$ ) (Vancouver Island and the Rocky Mountain parks of Canada). In Eurasia, Morozov (1951) found T. hydatigena in 12 of 20 wolves from the Mordvinian National Reserve, in the Middle Volga region; Petrov and Potekhina (1953) observed it in 1 of 2 animals examined in Tadzhikistan; Bondareva (1955) found the species twice among 12 animals autopsied in Kazakhstan; Rodonaia (1956) reported it from wolves in the Ladogan National Reserve, in the Leningrad area.

Wolves become infected through feeding upon deer, of which various species serve as the intermediate host of T. hydatigena. In Alaska, we have found the cysticerci in moose, Alces alces gigas Miller, and in caribou, Rangifer tarandus stonei Allen, wherever we have been able to examine such animals. The larval cestodes are commonly seen in the liver of the host, where they are often encysted in the hepatic surface just beneath the capsule. We have recorded a maximum number of 51 cysticerci from the liver of an old moose killed near Anchorage.

The larval T. hydatigena was first recorded from North American moose by Hall (1919), who reported it also in woodland caribou, Rangifer caribou (Gmelin), and in black-tailed deer, Odocoileus hemionus (Raffinesque). Ritcey and Edwards (1958) found it in 84\% of 32 moose examined in British Columbia. Fenstermacher and Jellison (1933) reported an infected moose in Minnesota. Choquette et al. (1957) found this larval cestode to be the most common helminth in reindeer in the region of Aklavik, N.W. T. Gregson (1937) recorded it from a black-tailed deer in British Columbia, and Olsen and Fenstermacher (1943) found it in a white-tailed deer, O. virginianus (Zimmermann), in Minnesota. Cowan (1951) reported the cysticerci from several species of wild ruminants in British Columbia and Alberta. The Canadian records have been reviewed by Sweatman and Plummer (1957), who also made a detailed investigation of the larval development of this cestode. Machul'skii (1950) observed the cysticerci in 2 moose killed in Buriat-Mongolia.

\section{Taenia krabbei Moniez, 1879}

This cestode was found in $48(61 \%)$ of 78 wolves. There appears to be no previous North American record from this host-species, but Morozov (1951) reported T. krabbei from 4 of 20 wolves examined in the Mordvinian National Reserve, in the western USSR.

The larval T. krabbei is a common parasite of caribou. Since these cysticerci are relatively small, and occur in the musculature of the host, it is difficult to determine 
Rausch \& Williamson in Journal of Parasitology (August 1959) v. 45, no. 4, section 1.

Copyright 1959, American Society of Parasitologists. Used by permission.

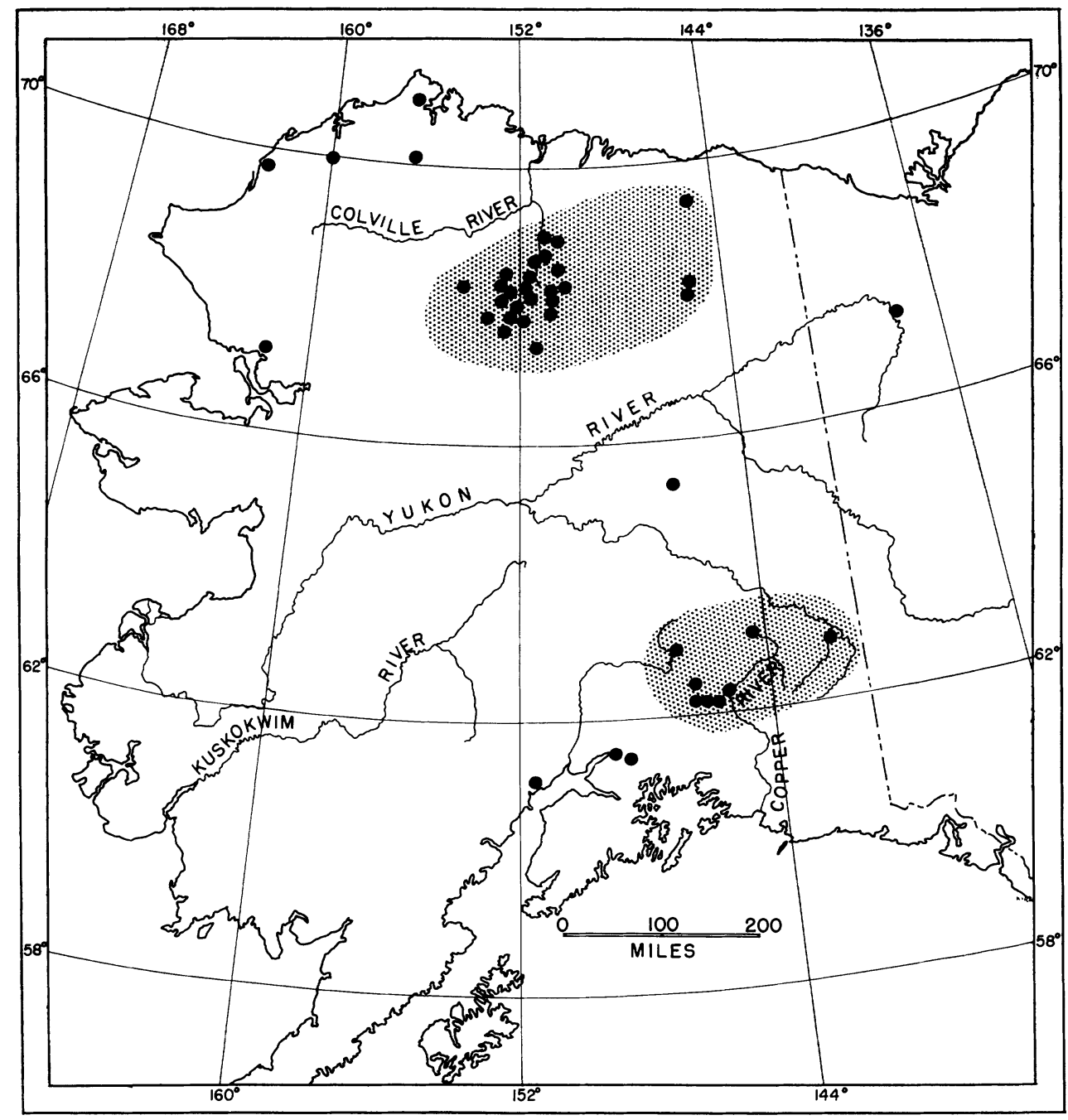

Explanation of Figure

Figure 1. Map of Alaska showing localities from which wolves were examined. The shaded areas indicate the central Brooks Range (to the north) and the Copper River drainage.

the infection rate accurately. We have observed infected caribou most frequently in the central Brooks Range region of northern Alaska, but they are often seen also in the Nelchina region of southern Alaska. We have not been able to examine any moose from regions where wolves are numerous, but this parasite is rare in moose in southern Alaska. Peterson (1955) reviewed records from moose and caribou in Canada, and Choquette et al. (1957) found 12.8\% infected of 1664 reindeer examined over a 3-year period at Aklavik. Erickson and Highby (1942) reported these cysticerci from a woodland caribou in Saskatchewan. It is known to occur in reindeer in the Soviet Union (Skriabin, 1931), and in deer of other species in western Eurasia. 
Rausch \& Williamson in Journal of Parasitology (August 1959) v. 45, no. 4, section 1.

Copyright 1959, American Society of Parasitologists. Used by permission.

Taenia multiceps Leske, 1780

As pointed out by Cameron (1926), there is no justification for the retention of Multiceps as a genus distinct from Taenia. Our material is designated T. multiceps, in accordance with the conclusions of Clapham (1942), but the name T. serialis Gervais, 1847, would be applicable if Clapham's findings were not accepted.

T. multiceps was identified in $23(29 \%)$ of 78 wolves. The only other North American record from this host appears to be that of Erickson (1944), in Minnesota. Bondareva (1955) reported it from a wolf in Kazakhstan.

We have collected the larval cestodes from hares, Lepus americanus Erxleben, in southern Alaska during years when these animals were numerous. The hooks obtained from the larvae closely resembled in size and shape those of the adult cestodes taken from wolves. Larvae of $T$. multiceps have not been observed in hares from northern Alaska, nor in mammals of other species.

\section{Genus Echinococcus Rudolphi, 1810}

\section{Echinococcus granulosus (Batsch, 1786)}

E. granulosus was found in $60(30 \%)$ of the 200 wolves autopsied. It was first reported from North American wolves by Riley (1933), in Minnesota; Erickson (1944) reported it from the same region. DeVos and Allin (1949) considered E. granulosus to be the most common cestode in wolves in Ontario ; here also, Sweatman (1952) found $36(62 \%)$ infected of 58 animals examined. Cowan (1947) reported an infected wolf from the Rocky Mountain parks of Canada and (1948) one from Alberta. Echinococcus sp. from a wolf in Macedonia was studied by Cameron (1926) and Bondareva (1955) recorded E. granulosus in 1 of 12 wolves autopsied in Kazakhstan.

Deer of various species serve as the intermediate host of E. granulosus, caribou and moose being the important species in boreal North America. The larval cestodes are found commonly in the lungs of moose in the lower Matanuska River valley, in southern Alaska (Rausch, 1952); this is an agricultural area from which wolves are generally absent, and dogs probably are the only important final host. Here, R. A. Rausch (1959) observed an infection rate of $63 \%$ in 16 moose which were all at least 7 years old. In 124 moose from the Anchorage-Palmer area, representing all age-classes, he found the rate of infection to be $20 \%$. A maximum number of 18 cysts has been observed in the lungs of a single moose (Rausch, 1952).

Infected moose have been reported in Canada by Hadwen (1932) (Manitoba), Law and Kennedy (1933), deVos and Allin (1949), and Sweatman (1952) (Ontario). Harper et al. (1955) found 29 moose infected of 96 examined in Saskatchewan, and Ritcey and Edwards (1958) observed the larvae in 68\% of the animals autopsied in British Columbia. The records of the larval E. granulosus from moose have been reviewed by Peterson (1955). Farther south, infected moose have been reported by Riley $(1933 ; 1939)$, Fenstermacher and Jellison (1933), and Olsen and Fenstermacher (1942) (Minnesota). Sweatman (1952) cited a record from Isle Royale.

Our observations indicate that the rate of infection in caribou in Alaska is relatively low. Since 1949, Rausch has examined grossly the lungs of more than 200 caribou from the central Brooks Range without having found any infected. A single pulmonary cyst was observed in an old bull in the Nelchina area (Rausch, 1952). In the latter area during 1956-57, R. O. Skoog, U. S. Fish and Wildlife 
Rausch \& Williamson in Journal of Parasitology (August 1959) v. 45, no. 4, section 1.

Copyright 1959, American Society of Parasitologists. Used by permission.

Service, examined 67 caribou representing all age-classes; of these, only 4 animals, all at least 7 years old, were infected (personal communication). Banfield (1951) reported infected caribou from northern Manitoba and from the Northwest Territories, and Sweatman (1952) cited a record from the Keewatin District. Harper et al. (1955) found 3 caribou infected among 14 examined in Saskatchewan.

Hadwen and Palmer (1922) implied that Alaskan reindeer are sometimes infected, although specific records were not given. We have not found this parasite in reindeer on Nunivak Island, nor have we any information about its occurrence in the smaller herds on the mainland of Alaska. Over a 3-year period, Choquette et al. (1957) noted an infection rate of $9.5 \%$ for 1664 deer examined at Aklavik, N. W. T. E. granulosus is a common parasite of reindeer in northern Scandinavia (cf. Söderhjelm, 1945 ; 1946), and is known also from reindeer in the Soviet Union (cf. Skriabin, 1931).

In North America, deer of other species are sometimes found infected. We have one record from a black-tailed deer from Baranof Island, southeastern Alaska, where wolves are not known to occur. The same species has been found infected on Vancouver Island and in Alberta by Cowan (1946). Riley (1939) found this cestode in 1 of 58 white-tailed deer examined in Minnesota, and Olsen and Fenstermacher (1943) also reported it from this host-species in the same area. Harper et al. (1955) recorded 2 infected white-tailed deer in Saskatchewan, and Sweatman (1952) found a single animal infected among 353 examined in Ontario. Green (1949) examined the lungs of 1,073 wapiti, Cervus canadensis (Erxleben), over a 4-year period in Alberta, where he observed the larval E. granulosus in 57 animals $(5 \%)$, most of which were over 2 years of age.

We also have identified this parasite in a mountain goat, Oreamnos americanus (Blainville), which was shot near the head of the Lynn Canal, southeastern Alaska. This animal had 2 pulmonary cysts, of which the larger measured $70 \mathrm{~mm}$. in diameter.

\section{TREMATODA}

Genus Alaria Schrank, 1788

Alaria canis LaRue and Fallis, 1936

$A$. canis was the only species of trematode recorded from Alaskan wolves; it was found in $8(4 \%)$ of the 200 animals autopsied. The occurrence of this parasite in wolves has been mentioned by Babero and Rausch (1952). The only other published record from this host appears to be that of Pearson (1956), who found it in 10 of 34 wolves autopsied in Ontario.

According to the findings of Pearson (1956), it would be possible for wolves to become infected through eating frogs containing the mesocercariae of $A$. canis. Possibly, also, a paratenic host, probably a rodent, is involved. One species of frog, Rana sylvatica cantabrigensis Baird, is widely distributed in Alaska, with its range restricted essentially to the taiga zone. Only $1(0.6 \%)$ of 162 wolves from the Brooks Range was infected. By comparison, 7 (25\%) of 27 animals from the Copper River drainage in southern Alaska, where frogs are numerous, were infected (Fig. 1).

3. NEMATODA

Genus Trichinella Railliet, 1895

Trichinella spiralis (Owen, 1835) 
Rausch \& Williamson in Journal of Parasitology (August 1959) v. 45, no. 4, section 1.

Copyright 1959, American Society of Parasitologists. Used by permission.

Larval nematodes of the genus Trichinella, identified as $T$. spiralis, were found in $51(33 \%)$ of the 154 wolves examined for this parasite. The occurrence of this nematode in wolves has been discussed elsewhere (Rausch et al., 1956).

Genus Uncinaria Froelich, 1789

Lncinaria stenocephala (Railliet, 1884)

This hookworm was collected from $14(7 \%)$ of the 200 wolves examined. $U$. stenocephala was first recorded from North American wolves by Erickson (1944), who found it to be rather common in these animals in northern Minnesota. Rodonaia (1956) reported it from wolves in the Ladogan National Reserve.

Only $7(4 \%)$ of the 162 wolves from the central Brooks Range were infected, compared with $7(25 \%)$ of 27 animals from the Copper River drainage. Although the latter series is too small to permit any definite conclusions, the difference in infection rates between the tundra and taiga zones appears significant.

\section{Genus Toxascaris Leiper, 1907}

\section{Toxascaris leonina (von Linstow, 1902)}

T. leonina was a very common parasite, occurring in $144(72 \%)$ of the wolves. There appears to be no previous record from this host in North America. Morozov (1951) found it in 4 of 20 animals examined in the Mordvinian National Reserve, and Petrov and Potekhina (1953) reported it from 2 wolves in Tadzhikistan.

Of 162 wolves from the central Brooks Range, $136(84 \%)$ were infected, as compared with only $6(22 \%)$ of 27 animals from the Copper River drainage. It was not unusual to find 50 to 60 of these ascarids in an individual wolf, and a maximum number of 175 worms was noted in an animal from the Brooks Range.

\section{DISCUSSION}

Eight species of helminths were recorded from Alaskan wolves in the course of the present survey. Of these, 6 occurred commonly and 2 were found in less than $10 \%$ of the 200 animals considered. The number of species in wolves is small compared with what we have observed in other Alaskan canids (e.g., dog and arctic fox), perhaps indicating that wolves have much more restricted feeding habits.

Wolves are found throughout the taiga and tundra zones of Alaska, excepting those regions where wild ruminants are absent, or where they have been driven out by man. During the colder months, wolves follow the migrating herds of caribou, upon which they depend. The most diversified diet is had during the spring and early summer, when they remain in the vicinity of the den; during this time, any animals that can be captured are used as food. Carrion is sometimes consumed, but it usually comprises a small proportion of their diet.

Caribou and moose serve as the intermediate host for Taenia hydatigena, $T$. krabbei, and Echinococcus granulosus. The larvae of the first 2 species occur so commonly in caribou that it would seem impossible that any wolf could long remain uninfected. There is some evidence that wolves kill a disproportionally large number of aged caribou; this would increase the probability of their ingesting the larvae of the aforementioned species of cestodes, since the infection rate is known to increase with age in these deer. Aside from the fact that wolves often travel in close association with herds of caribou, and deposit their feces where caribou feed, noth- 
Rausch \& Williamson in Journal of Parasitology (August 1959) v. 45, no. 4, section 1.

Copyright 1959, American Society of Parasitologists. Used by permission.

ing is known about the infection of the intermediate host of these cestodes. Opportunities for their becoming infected would seem to be much reduced by the fact that they rarely feed long in one area. Seasonal differences in feeding behavior may be important. Söderhjelm (1946) and others have pointed out that reindeer seek out and eat urine-soaked snow, but it has not been reported whether they also may eat feces of canine animals.

T. multiceps occurs in larval form in hares, but hares do not generally comprise an important part of the diet of wolves. It is conceivable that in years when hares are especially numerous they may become an important food of wolves, since abundance and availability of a prey-species seem to determine the degree to which it is preyed upon. At times of high population density of hares, many may be utilized when the young wolves are in the den. It has not been possible to obtain information which would permit any correlation between the abundance of hares and the prevalence of $T$. multiceps in wolves, although the infected animals reported herein were killed during years immediately preceding a peak hare population in the central Brooks Range. If wolves in Alaska become infected only from hares, the prevalence rate of $T$. multiceps would be expected to decrease during times of hare scarcity.

Both Trichinella spiralis and Alaria canis are acquired by wolves from animals other than the aforementioned cervids. The specific origin of Trichinella larvae is unknown, although there are several possible sources (Rausch et al., 1956). In the case of $A$. canis, wolves may ingest mesocercariae in frogs, or they may become infected through some paratenic host. It appears doubtful that microtine rodents eat frogs or their larvae, although such rodents may be more omnivorous than is now recognized.

Toxascaris leonina can develop directly in the final host when infective eggs are ingested by a susceptible animal, or infection may be acquired through the eating of rodents containing the encysted larvae (Sprent, 1954). During the spring and early summer, eggs eliminated by the adult wolves in the vicinity of the dens would have time to become infective to the pups before the latter left the den area. The situation appears similar in the case of Uncinaria stenocephala. For both species, the adult wolves probably serve as reservoir hosts from which the young animals indirectly become infected. There is no evidence that the eggs of either species can survive the low winter temperatures characteristic of the higher latitudes.

Besides those species recorded from Alaskan wolves, several helminths, to all appearances characteristic of a more southern fauna, have been reported in wolves at lower latitudes in both North America and Eurasia. Certain others, such as Diphyllobothrium spp., can be expected; the presence of Diphyllobothrium sp. in a wolf in Ontario (deVos and Allin, 1949) may not be unusual, since these animals must on occasion capture and eat fishes containing plerocercoids of Diphyllobothrium. Another species, Echinococcus multilocularis Leuckart, 1863, has been grown experimentally in a wolf (Rausch, 1959); its natural occurrence in this host in Alaska would depend upon the utilization of microtine rodents in certain regions. A few species of helminths, e.g., Alaria alata (Goeze, 1782), are as far as is known distributionally restricted to Eurasia.

The parasites of Alaskan wolves recognized as being pathogenic to man are Echinococcus granulosus and Trichinella spiralis, although it is improbable that either is often transmitted directly from wolves to man. Infection by the former 
Rausch \& Williamson in Journal of Parasitology (August 1959) v. 45, no. 4, section 1.

Copyright 1959, American Society of Parasitologists. Used by permission.

may occur in hunters and trappers through their accidental ingestion of Echinococcus eggs after handling wolf carcasses, but the casual infection from this source seems insignificant upon realization that the same hunters may live in close association with infected dogs.

\section{SUMMARY}

Two hundred wolves, Canis lupus, L., have been examined for parasitic helminths over a 10-year period in Alaska. Most of these animals (162) were killed in the Brooks Range region of arctic Alaska.

Eight species of helminths have been identified: Taenia hydatigena Pallas, 1776; T. krabbei Moniez, 1879; T. multiceps Leske, 1780; Echinococcus granulosus (Batsch, 1786) ; Alaria canis LaRue and Fallis, 1936; Trichinella spiralis (Owen, 1835 ) ; Uncinaria stenocephala (Railliet, 1884) ; Toxascaris leonina (von Linstow, 1902).

Observations on the occurrence, distribution, and natural history of these helminths have been presented, with a review of pertinent literature.

Two species, Echinococcus granulosus and Trichinella spiralis, are pathogenic for man, but it is concluded that wolves have little importance as reservoir hosts from which man may be infected.

\section{ACKNOWLEDGMENTS}

Personnel of the U. S. Fish and Wildlife Service made available wolf carcasses from southern Alaska, and others were obtained through the assistance of the Arctic Research Laboratory, Office of Naval Research, at Point Barrow. Dr. J. F. A. Sprent, University of Queensland Veterinary School, Brisbane, Australia, made detailed studies of a series of Toxascaris leonina from Alaskan canids. We wish to express our appreciation for this assistance.

\section{Literature Cited}

Babero, B. B. and Rausch, R. 1952 Notes on some trematodes parasitic in Alaskan Canidae. Proc. Helm. Soc. Wash. 19: 15-17.

Banfield, A. W. F. 1951 The Barren-Ground Caribou. Dept. Res. and Dev., Ottawa. 52 pp. (Mimeo.)

BondareVA, V. I. 1955 Rol' domashnikh i dikikh plotoiadnykh v epidemiologii i epizootologii larval'nykh tsestodozov. II. Fauna tsestod volkov. Trudy Inst. Zool., Akad. Nauk Kazakhsk. SSR 3: 101-104.

Cameron, T. W. M. 1926 Observations on the genus Echinococcus Rudolphi, 1801. J. Helm. 4: 13-22.

Choquette, L. P. E., Whitten, L. K., Rankin, G. and Seal, C. M. 1957 Note on parasites found in reindeer (Rangifer tarandus) in Canada. Can. J. Comp. Med. 21: 199-203.

Clapham, P. A. 1942 On identifying Multiceps spp. by measurement of the large hook. J. Helm. $20: 31-40$.

Cowan, I. MCT. 1946 Parasites, diseases, injuries, and anomalies of the Columbian blacktailed deer, Odocoileus hemionus columbianus (Richardson), in British Columbia. Can. J. Res. D 24: 71-103.

1947 The timber wolf in the Rocky Mountain National Parks of Canada. Can. J. Res. 25: 139-174.

1948 The occurrence of the granular tape-worm Echinococcus granulosus in wild game in North America. J. Wildl. Mgt. 12: 105-106.

1951 The diseases and parasites of big game mammals of western Canada. Proc. 5th Ann. Game Conv., 1951. Pp. 37-64.

deVos, A. And Allin, A. E. 1949 Some notes on moose parasites. J. Mammal. 30: 430-431.

Erickson, A. B. 1944 Helminths of Minnesota Canidae in relation to food habits, and a host list and key to the species reported from North America. Am. Midl. Nat. 32: 358-372.

$\rightarrow$ And Highby, P. R. 1942 Parasites of the woodland caribou. J. Parasit. 28: 423. 
Rausch \& Williamson in Journal of Parasitology (August 1959) v. 45, no. 4, section 1.

Copyright 1959, American Society of Parasitologists. Used by permission.

Fenstermacher, R. and Jellison, W. L. 1933 Diseases affecting moose. Univ. Minn. Agric. Exp. Sta. Bull. 294. 20 pp.

Green, H. U. 1949 Occurrence of Echinococcus granulosus in elk (Cervus canadensis nelsoni), Banff National Park. Can. Field-Nat. 63: 204-205.

Gregson, J. D. 1937 Cysticercosis in deer. Parasitol. 29: 409.

Hadwen, S. 1932 [Untitled note on parasites of moose.] Proc. Helm. Soc. Wash. in J. Parasit. 19: 83.

And Palmer, L. J. 1922 Reindeer in Alaska. U. S. Dept. Agric. Bull. 1089. 74 pp.

Hall, M. C. 1919 The adult taenioid cestodes of dogs and cats, and of related carnivores in North America. Proc. U. S. Natl. Mus. 55: 1-94.

Harper, T. A., Ruttan, R. A. and Benson, W. A. 1955 Hydatid disease (Echinococcus granulosus) in Saskatchewan big game. Trans. 20th N. Am. Wild1. Conf., 1955. Pp. 198-208.

Law, R. G. ANd Kennedy, A. H. 1933 Echinococcus granulosus in a moose. N. Am. Vet. 14: 33-34.

Machul'skin, S. N. 1950 Gel'minty losei Buriat-Mongolii. Doklad. Akad. Nauk SSSR 73: 1313-1315.

Morozov, F. N. 1951 Gel'minty volkov mordovskogo gosudarstvennogo zapovednika. Trudy Gel'mint. Lab. 5: 146-149.

Olsen, O. W. and Fenstermacher, R. 1942 Parasites of moose in northern Minnesota. Am. J. Vet. Res. 3: 403-408.

— AND 1943 The helminths of North American deer. With special reference to those of the white-tailed deer (Odocoileus virginianus borealis) in Minnesota. Univ. Minn. Agric. Exp. Sta. Tech. Bull. 159. 20 pp.

Pearson, J. C. 1956 Studies on the life cycles and morphology of the larval stages of Alaria arisaemoides Augustine and Uribe, 1927 and Alaria canis LaRue and Fallis, 1936 (Trematoda: Diplostomidae). Can. J. Zool. 34: 295-387.

Peterson, R. L. 1955 North American moose. Univ. Toronto Press, Toronto. 280 pp.

Petrov, A. M. And Potekhina, L. F. 1953 K gel'mintofaune khishchnykh i mlekopitaiushchikh Tadzhikistana. Trudy Vsesoiuz. Inst. Gel'mint. 5: 82-94.

Rausch, R. 1952 Hydatid disease in boreal regions. Arctic 5: 157-174. 1959 Echinococcus multilocularis infection. Proc. 6th Internatl. Cong. Trop. Med. and Mal. In press.

$\rightarrow-$ Babero, B. B., Rausch, R. V. ANd Schiller, E. L. 1956 Studies on the helminth fauna of Alaska. XXVII. The occurrence of larvae of Trichinella spiralis in Alaskan mammals. J. Parasit. 42: 259-271.

Rausch, R. A. 1959 Notes on prevalence of hydatid disease in Alaskan moose. J. Wildl. Mgt. 23: 122-123.

RILEy, W. A. 1933 Reservoirs of Echinococcus in Minnesota. Minn. Med. 16: 744-745. 1939 Maintenance of Echinococcus in the United States. J. Am. Vet. Med. As. 95: 170-172.

Ritcey, R. W. ANd Edwards, R. Y. 1958 Parasites and diseases of the Wells Gray moose herd. J. Mammal. 39: 139-145.

RodonaIA, T. E. 1956 Gel'mintofauna dikikh mlekopitaiushchikh Ladogekhskogo gosudarstvennogo zapovednika. Trudy Inst. Zool., Akad. Nauk Gruzinsk. SSR 14: 147-187.

Skriabin, K. I. 1931 Glistnye invazii severnogo olenia. Moscow-Leningrad. 86 pp.

SöDERHJELM, L. 1945 Förekomsten av Echinococcus hydatidosus hos människa och ren (Rangifer tarandus). Svenska Läkartidningen nr. 28. Pp. 1-7.

1946 Echinococcus hydatidosus hos ren (Rangifer tarandus). Skand. Vet.-Tidskr. 36: 378-381.

Sprent, J. F. A. 1954 The life cycles of nematodes in the family Ascarididae Blanchard 1896. J. Parasit. 40: 608-617.

Sweatman, G. K. 1952 Distribution and incidence of Echinococcus Granulosus in man and other animals with special reference to Canada. Can. J. Pub. Health 43: 480-486. And Plummer, P. J. G. 1957 The biology and pathology of the tapeworm Taenia hydatigena in domestic and wild hosts. Can. J. Zool. 35: 93-109. 